\title{
Vegetative Growth and Flowering of Primocane Raspberry 'Ariadne' as Affected by Prohexadione-calcium Treatments
}

\author{
Pauliina Palonen ${ }^{1}$ and Katriina Mouhu \\ Department of Applied Biology, Horticulture, P.O. Box 27, FIN-00014 \\ University of Helsinki, Helsinki, Finland
}

Additional index words. growth control, ProCa, Rubus idaeus

\begin{abstract}
Maintaining an appropriate balance between vegetative and generative growth is a prerequisite for profitable raspberry (Rubus idaeus $\mathbf{L}$.) production. The objective of our study was to test the effect of prohexadione-calcium (ProCa) on vegetative growth and flowering of primocane fruiting red raspberry 'Ariadne' in greenhouse conditions. ProCa was applied either once or twice in a concentration of $100 \mathrm{ppm}$ or $200 \mathrm{ppm}$. Double applications of ProCa reduced cane height by $33 \mathrm{~cm}(100 \mathrm{ppm})$ or by $46 \mathrm{~cm}(200 \mathrm{ppm})$. Growth reduction was the result of shortening of the internodes, because total node number in plants was unaffected. Furthermore, cane diameter was reduced in plants treated with $200 \mathrm{ppm}$ ProCa. ProCa treatments reduced the total aboveground dry weight by $32 \%$ to $55 \%$ but did not affect the allocation of dry weight into different plant parts. All ProCa treatments reduced the number of flowers by $22 \%$ to $42 \%$. In conclusion, ProCa proved effective in controlling vegetative growth of red raspberry. However, because the number of flowers was reduced, ProCa cannot be recommended for growth regulation of primocane fruiting raspberry without further studies.
\end{abstract}

Red raspberry (Rubus idaeus) has a relatively low harvest index, i.e., the relationship of harvestable crop to vegetative growth. When cultured in plastic tunnels or greenhouses, cane growth of raspberry plants is even more vigorous than in the field, and methods to control growth would be useful. The effect of traditional chemical growth retardants on raspberry has been reported in a few papers (Braun and Garth, 1984, 1986; Crandall and Garth, 1981; Ghora et al., 2000; Goulart, 1989; McGregor, 1987). However, their use is limited in fruit production.

Prohexadione-calcium (ProCa) is a gibberellin biosynthesis inhibitor, a fast degrading compound that has no negative effect on animals or soil micro-organisms (Evans et al., 1999). ProCa reduces levels of $\mathrm{GA}_{1}$ because it blocks the last steps of gibberellin biosynthesis, thus preventing the formation of active gibberellin, which causes accumulation of its immediate inactive precursors $\mathrm{GA}_{19}$ and $\mathrm{GA}_{20}$. As ProCa degrades, the accumulated precursors are converted into active gibberellin and growth restarts. ProCa has been reported to reduce vegetative growth in many cultivated fruit species (Lo Giudice et al., 2003; Owens and Stover, 1999; Reekie and Hicklenton, 2001; Southwick et al., 2004). Reduction in vegetative growth is mainly the result of shortening of internodes (Medjdoub et al., 2004, 2005). ProCa reduces vegetative growth and advances terminal bud

Received for publication 22 Dec. 2008. Accepted for publication 24 Jan. 2009.

${ }^{1}$ To whom reprint requests should be addressed; e-mail pauliina.palonen@helsinki.fi. set in apple trees (Malus $\times$ domestica Borkh.), thus reducing the need for pruning without affecting the crop in the next year (Byers et al., 2004; Greene, 1999; Guak et al., 2001; Medjdoub et al., 2004, 2005; Owens and Stover, 1999). Furthermore, increases in fruit set in the year of application have been reported for apple (Glenn and Miller, 2005) and pear (Pyrus communis L.) (Smit et al., 2005). Consequently, decrease in return bloom, more likely resulting from increased fruit set, has been reported for some pear cultivars (Smit et al., 2005; Sugar et al., 2004), whereas in others, ProCa had no effect on return bloom (Southwick et al., 2004). However, in grapevine (Vitis vinifera L.), prebloom applications resulted in substantial crop loss, although they were most effective in growth reduction (Lo Giudice et al., 2003). The influence of ProCa seems to be speciesand cultivar-dependent.

Because ProCa has proved effective in growth control of many fruit species, it might be applicable to control growth in raspberry cultivars as well. The aim of our study was to examine the effects of ProCa on growth and flowering in primocane fruiting red raspberry 'Ariadne'.

\section{Materials and Methods}

Primocane fruiting red raspberry 'Ariadne' plants propagated from root cuttings were received in $10-\mathrm{cm}$ pots from a commercial nursery (Marja-Suomen Taimituotanto, Suonenjoki, Finland). On 24 June 2003, they were planted in $3-\mathrm{L}$ pots in a peat-based potting mixture (Kekkilä Ruukutusseos,
NPK 11-4-21; Kekkilä, Tuusula, Finland) and pruned to a single cane per pot. Plants were grown outdoors on a sand bed during summer and drip-irrigated with $0.2 \%$ compound fertilizer solution (Puutarhan täyslannos, Kemira, NPK 14-5-21; Kemira GrowHow, Harjavalta, Finland). They were moved into a dark, cold storage $\left(1^{\circ} \mathrm{C}\right)$ on 17 Oct. After 45 $\mathrm{d}$, plants were pruned to soil level and transferred into a cold storage with temperature of $5{ }^{\circ} \mathrm{C}$ for $14 \mathrm{~d}$. On 15 Dec., when plants had accumulated a total of 1416 chilling hours, they were placed into a greenhouse compartment $\left(18{ }^{\circ} \mathrm{C}, 16-\mathrm{h}\right.$ photoperiod, $60 \%$ relative humidity). Light was provided with HPS lamps (OSRAM PlantaStar 400 W; Osram, Munchen, Germany) with a photon flux density of $225 \mu \mathrm{mol} \cdot \mathrm{m}^{-2} \cdot \mathrm{s}^{-1}$. Plants were dripirrigated with $0.1 \%$ compound fertilizer solution (Kekkilä Turve-Superex, NPK 12-5-27; Kekkilð, Tuusula, Finland).

On 9 Jan. 2004, when the plants had two to five fully expanded leaves, 45 plants were randomly assigned into three treatments and sprayed to drip-off with 0 (control), 100, or 200 ppm of ProCa [BAS 12510 W(BASF, Ludwigshafen, Germany), a.i. $10 \% \quad \mathrm{w} / \mathrm{w}$ ProCa] dissolved in water with $0.05 \%$ Tween 20 as a surfactant. There were 15 single plant replications per treatment. For eight plants per treatment, ProCa applications were repeated with the same concentrations 4 weeks later. Plant height, node number, cane diameter ( $3 \mathrm{~cm}$ above soil level), and the number of flowers were recorded weekly for 10 weeks until 19 Mar. At the end of the experiment, plants were harvested and partitioned into a main cane, leaves on a main cane, fruiting laterals (a stem and flowers), leaves on fruiting laterals, and vegetative branches. Vegetative branches were vigorous lateral shoots that originated from buds in the basal part of a cane and clearly differed in their growth habit from the other lateral shoots. Dry weights of these plant parts were determined by measuring oven dry weights $\left(70^{\circ} \mathrm{C}\right.$ for $\left.2 \mathrm{~d}\right)$.

The experiment was set up in a completely randomized design. Before data analysis, one replicate of plants that received a double treatment was arbitrarily selected and removed. Thus, there were seven single plant replicates per treatment. An analysis of variance was performed to test the significance of ProCa treatments on plant growth by using GLM procedure of SAS (SAS Institute Inc., Cary, NC). Where appropriate, treatment means were separated using Dunnett's test.

\section{Results}

In the beginning of the experiment, the average cane height was $25.9 \mathrm{~cm}$, cane diameter $4.1 \mathrm{~mm}$, and node number 3.8. Ten weeks later, at the end of the experiment, canes that were treated twice with ProCa were $29 \%$ to $41 \%$ shorter than the untreated control canes (Table 1). Cane diameter was reduced in plants treated with $200 \mathrm{ppm}$ ProCa either once or twice. The average total node number in canes was between 18.7 and 20.6 and unaffected by the treatment. 
Table 1. The effect of different prohexadione-calcium (ProCa) treatments (single application or two applications in 4-week intervals) on growth parameters of primocane raspberry 'Ariadne' measured 10 weeks after the first application. ${ }^{\mathrm{z}}$

\begin{tabular}{|c|c|c|c|c|c|c|c|}
\hline ProCa concn (ppm) & Cane ht $(\mathrm{cm})$ & Cane diam $(\mathrm{mm})^{\mathrm{y}}$ & Cane dry wt (g) & Node number & Internode length $(\mathrm{cm})^{x}$ & Flower number & Total dry wt (g) \\
\hline 0 (control) & 118 & 7.9 & 11.5 & 20.6 & 5.2 & 89 & 57.9 \\
\hline 100 & 96 & 7.5 & 8.2 & 19.3 & $4.3^{*}$ & $62 *$ & $39.3 *$ \\
\hline 200 & 92 & $7.0^{*}$ & $7.4^{*}$ & 20.3 & $3.8^{*}$ & $52 *$ & $30.0^{*}$ \\
\hline $0+0$ (control) & 113 & 7.1 & 9.3 & 20.6 & 5.2 & 78 & 51.0 \\
\hline $100+100$ & $80 *$ & 6.4 & $5.4^{*}$ & 19.3 & $3.3 *$ & $61 *$ & $26.7 *$ \\
\hline $200+200$ & $67 *$ & $6.2 *$ & $4.0 *$ & 18.7 & $2.7^{*}$ & $56^{*}$ & $22.9 *$ \\
\hline$P$ value in analysis & $<0.001$ & $<0.001$ & $<0.001$ & NS & $<0.001$ & $<0.001$ & $<0.001$ \\
\hline
\end{tabular}

of variance

${ }^{\mathrm{z}}$ Means marked with an asterisk are different from a corresponding control at $P \leq 0.05$ by Dunnett's test ( $\mathrm{n}=7$ ).

${ }^{\mathrm{y}}$ Measured $3 \mathrm{~cm}$ above the soil level.

${ }^{x}$ Internodes that developed after the treatments were initiated.

The average length of the internodes formed after the applications was reduced by all ProCa treatments (Table 1). For 3 weeks after the first ProCa application, new internodes in the treated plants were shorter than in the controls (data not shown). The effect of the second ProCa treatment was observed for 2 weeks after the application. Seven weeks after the first application, the new internodes in the plants that received a single application were $7.5 \mathrm{~cm}(100 \mathrm{ppm})$ and $7.3 \mathrm{~cm}(200 \mathrm{ppm})$ on an average compared with 4.0 and $3.3 \mathrm{~cm}$ in control treatments $(P=0.045)$. However, the treated plants did not differ significantly from the controls by Dunnett's test. Treatments also affected growth cessation; 7 weeks after the initiation of the treatments, only two of the seven plants treated twice with 200 ppm ProCa were producing new nodes, whereas of the plants treated once, five were actively growing.

All ProCa treatments reduced the total number of flowers in plants (Table 1). Furthermore, the total aboveground plant dry weight was reduced by all ProCa treatments (Table 1). Dry weight of a main cane was reduced in plants treated twice with $\mathrm{ProCa}$ and by a single application of $200 \mathrm{ppm}$ ProCa. Treating the plants twice with 200 ppm ProCa reduced the dry weight of the leaves on a main cane and dry weight of fruiting laterals (data not shown). The dry weight of vegetative branches was reduced by treating the plants once with $200 \mathrm{ppm}$ ProCa and by both double applications. The allocation of dry weight into different plant parts (percentage of total aboveground dry weight accumulation) was unaffected by the treatments. On average, $20 \%$ of the aboveground dry weight was allocated into a main cane, $32 \%$ into the leaves on a main cane, $18 \%$ into the fruiting laterals, $6 \%$ into the leaves on fruiting laterals, and $25 \%$ into the vegetative branches.

\section{Discussion}

ProCa reduced vegetative growth of primocane raspberry 'Ariadne' as has been reported for a few other fruit species (Lo Giudice et al., 2003; Owens and Stover, 1999; Reekie and Hicklenton, 2001; Southwick et al., 2004). Cane height was reduced by $33 \mathrm{~cm}$ and $46 \mathrm{~cm}$ in the plants treated twice with $100 \mathrm{ppm}$ and $200 \mathrm{ppm}$ ProCa, respectively. Thus, ProCa treatment might reduce the trellising requirement of primocane rasp- berries. Growth reduction was the result of shortening of the internodes, because total node number in plants was unaffected. Cane diameter was reduced by treating the plants either once or twice with 200 ppm ProCa.

ProCa affected the length of the internodes formed during the first 3 weeks after the application. Four weeks after the treatment, the effect had disappeared indicating that ProCa rapidly breaks down in a plant. Therefore, several applications during the growing season are needed for effective growth control. The extent of growth control is dependent on both timing and number of applications (Medjdoub et al., 2004, 2005). In strawberry (Fragaria $\times$ ananassa Duch.), the effect of one ProCa application lasts for $\approx 3$ weeks and repeated applications are needed to effectively control plant height (Reekie and Hicklenton, 2001). For apple, application should be made 0 to $12 \mathrm{~d}$ after full bloom; later in the season, the effect is weaker, possibly as a result of high concentrations of $\mathrm{GA}_{1}$ already accumulated in the shoot tissues (Medjdoub et al., 2005). Two applications in 6- to 8-week intervals were needed to avoid regrowth of the shoots (Medjdoub et al., 2004). In another experiment, three applications at 2 -week intervals beginning at petal fall reduced terminal shoot growth by $59 \%$ (Glenn and Miller, 2005). For raspberry, ProCa applications at 3-week intervals might be recommended.

Seven weeks after ProCa treatments were initiated, raspberry plants that received a single application produced longer internodes than the control plants. The differences were not significant by Dunnett's test, probably because a few plants had already stopped producing new internodes, so variation was high. Also in strawberry, increased growth above the control level occurred 9 weeks after ProCa application (Reekie and Hicklenton, 2001). ProCa blocks the last steps in gibberellin biosynthesis pathways, which leads to accumulation of immediate precursors of active gibberellin (Evans et al., 1999). When ProCa breaks down, the accumulated precursors are converted into active gibberellin, and growth rate may even exceed the normal growth as a result of excess amount of active gibberellin available in a plant. The second treatment was needed to suppress growth after breakdown of ProCa in raspberry.

Because the number of flowers was reduced in all ProCa-treated plants by $22 \%$ to $42 \%$, altered GA levels in the plant have apparently interfered with floral induction. Second treatment did not further suppress flowering, possibly because at that time, flower initiation was completed. Detailed knowledge on the role of distinct GAs on flower induction in raspberry is lacking. However, Vasilakakis et al. (1979) reported that increased GA levels in the shoot tip were associated with flower induction in primocane fruiting raspberry. In apple tree, in which GAs have been implicated in flower inhibition, ProCa application increased flowering by 20\% (Owens and Stover, 1999). In primocane raspberries, vegetative and generative growth are coincident. However, in floricane raspberries, vegetative growth and floral induction are temporally separated, which may facilitate manipulation of vegetative growth without affecting flower induction. Apparently, timing of ProCa application is extremely crucial and requires careful examination.

Total aboveground dry weight of raspberry plants was drastically reduced by ProCa treatments: $32 \%$ to $48 \%$ by single applications and $48 \%$ to $55 \%$ by double applications. However, the allocation of dry weight into different aboveground plant parts was unaffected. ProCa did not alter allocation of total nonstructural carbohydrates in apple trees either (Guak et al., 2001). However, in strawberry, ProCa-treated plants allocated more dry weight to roots and proportionally less to shoots (Reekie et al., 2005).

In conclusion, ProCa reduced cane growth and internode length in primocane fruiting raspberry 'Ariadne'. Treatment with $200 \mathrm{ppm}$ ProCa twice in 4-week intervals caused the most effective reduction in vegetative growth. However, the number of flowers was drastically reduced in all ProCa-treated plants. Therefore, ProCa cannot be recommended for growth regulation of primocane fruiting raspberry without further studies.

\section{Literature Cited}

Braun, J.W. and J.K.L. Garth. 1984. Growth and fruiting of 'Heritage' primocane fruiting red raspberry in response to daminozide and ethephon. J. Amer. Soc. Hort. Sci. 109:207-209.

Braun, J.W. and J.K.L. Garth. 1986. Growth and fruiting of 'Heritage' primocane fruiting red raspberry in response to paclobutrazol. HortScience 21:437-439.

Byers, R.E., D.H. Carbaugh, and L.D. Combs. 2004. The influence of prohexadione-calcium sprays on apple tree growth, chemical fruit 
thinning, and return bloom. J. Amer. Pomol. Soc. 58:111-117.

Crandall, P.C. and J.K.L. Garth. 1981. Yield and growth response of 'Heritage' raspberry to daminozide and ethephon. HortScience 16:654 655.

Evans, J.R., R.R. Evans, C.L. Regusci, and W. Rademacher. 1999. Mode of action, metabolism, and uptake of BAS 125W, prohexadionecalcium. HortScience 34:1200-1201.

Ghora, Y., M. Vasilakakis, and G. Stavroulakis. 2000. Effect of growth retardants (cycocel, daminozide and paclobutrazol) on growth and development of red raspberries, cv. Autumn Bliss, cultivated under plastic greenhouse conditions in Chania-Crete, Greece. Acta Hort. 513:453-458.

Glenn, D.M. and S.S. Miller. 2005. Effects of Apogee on growth and whole-canopy photosynthesis in spur 'Delicious' apple trees. HortScience 40:397-400.

Goulart, B.L. 1989. Growth and flowering of greenhouse-grown red raspberry treated with plant growth regulators. HortScience 24:296298.

Greene, D.W. 1999. Tree growth management and fruit quality of apple trees treated with prohexadione-calcium (BAS 125). HortScience 34:1209-1212.

Guak, S., D. Neilsen, and N.E. Looney. 2001. Growth, allocation of $\mathrm{N}$ and carbohydrates, and stomatal conductance of greenhouse grown apple treated with prohexadione-Ca and gibberellins. J. Hort. Sci. Biotechnol. 76:746-752.

Lo Giudice, D., T.K. Wolf, and R.P. Marini. 2003. Vegetative response of Vitis vinifera to prohexadione-calcium. HortScience 38:14351438.

McGregor, G.R. 1987. Daminozide affects growth and yield of 'Heritage' red raspberry. HortScience 22:38-40.

Medjdoub, R., J. Val, and A. Blanco. 2004. Prohexadione-Ca inhibits vegetative growth of 'Smoothee Golden Delicious' apple trees. Scientia Hort. 101:243-253.

Medjdoub, R., J. Val, and A. Blanco. 2005 Inhibition of vegetative growth in red apple cultivars using prohexadione-calcium. J. Hort. Sci. Biotechnol. 80:263-271.

Owens, C.L. and E. Stover. 1999. Vegetative growth and flowering of young apple trees in response to prohexadione-calcium. HortScience 34:1194-1196.
Reekie, J.Y., P.R. Hicklenton, and P.C. Struik. 2005. Prohexadione-calcium modifies growth and increases photosynthesis in strawberry nursery plants. Can. J. Plant Sci. 85:671-677.

Reekie, J.Y.-C. and P.R. Hicklenton. 2001. Strawberry growth response to prohexadionecalcium. Strawberry research to 2001. Proceedings of the 5th North American Strawberry Conference 5:147-152.

Smit, M., J.J. Meintjes, G. Jacobs, P.J.C. Stassen, and K.I. Theron. 2005. Shoot growth control of pear trees (Pyrus communis L.) with prohexadione-calcium. Scientia Hort. 106:515-529.

Southwick, S.M., C. Ingels, R. Hansen, and K. Glozer. 2004. The effects of Apogee on shoot growth, secondary flowering, fire blight, fruit quality, yield and return bloom in 'Bartlett' pear growing in California. J. Hort. Sci. Biotechnol. 79:380-389.

Sugar, D., D.C. Elfving, and E.A. Mielke. 2004. Effects of prohexadione-calcium on fruit size and return bloom in pear. HortScience 39: 1305-1308.

Vasilakakis, M.D., B.H. McCown, and M.N. Dana. 1979. Hormonal changes associated with growth and development of red raspberries. Physiol. Plant. 45:17-22. 